\title{
Assessment of combined toxicity of heavy metals from industrial wastewaters on Photobacterium phosphoreum T3S
}

\author{
BibiSaima Zeb ${ }^{1,2} \cdot$ Zheng Ping $^{1}$ Q Qaisar Mahmood ${ }^{2}$ Qiu Lin ${ }^{1} \cdot$ Arshid Pervez $^{2}$ • \\ Muhammad Irshad $^{2} \cdot$ Muhammad Bilal $^{2} \cdot$ Zulfiqar Ahmad Bhatti $^{2} \cdot$ \\ Shahida Shaheen ${ }^{2}$
}

Received: 19 May 2015/ Accepted: 19 January 2016/Published online: 9 February 2016

(c) The Author(s) 2016. This article is published with open access at Springerlink.com

\begin{abstract}
This research work is focusing on the toxicities of heavy metals of industrial origin to anaerobic digestion of the industrial wastewater. Photobacterium phosphoreum $\mathrm{T} 3 \mathrm{~S}$ was used as an indicator organism. The acute toxicities of heavy metals on $P$. phosphoreum T3S were assessed during 15-min half inhibitory concentration (IC50) as indicator at $\mathrm{pH}$ 5.5-6. Toxicity assays involved the assessment of multicomponent mixtures using TU and MTI approaches. The results of individual toxicity indicated that the toxicity of $\mathrm{Cd}, \mathrm{Cu}$ and $\mathrm{Pb}$ on $P$. phosphoreum increased with increasing concentrations and there was a linear correlation. The $15-\mathrm{min} \mathrm{IC}_{50}$ values of $\mathrm{Cd}, \mathrm{Cu}$ and $\mathrm{Pb}$ were $0.537,1.905$ and $1.231 \mathrm{mg} / \mathrm{L}$, respectively, and their toxic order was $\mathrm{Cd}>\mathrm{Pb}>\mathrm{Cu}$. The combined effects of $\mathrm{Cd}, \mathrm{Cu}$ and $\mathrm{Pb}$ were assayed by equivalent concentration mixing method. The results showed that the combined effects of $\mathrm{Cd}+\mathrm{Cu}, \mathrm{Cd}+\mathrm{Pb}, \mathrm{Cu}+\mathrm{Pb}$, $\mathrm{Cd}+\mathrm{Cu}+\mathrm{Pb}$ were antagonistic, antagonistic and partly additive. The combined effect of three heavy metals was partly additive.
\end{abstract}

Keywords Heavy metals - Photobacterium - Acute toxicity $\cdot$ Wastewater treatment

Qaisar Mahmood

mahmoodzju@gmail.com

1 Department of Environmental Engineering, Zhejiang University, Hangzhou, 310058, China

2 Department of Environmental Sciences, COMSATS Institute of Information Technology, Abbottabad 22060, Pakistan

\section{Introduction}

The presence of heavy metals in excess amounts interferes with the beneficial uses of water because of the toxicity of heavy metals and the biomagnification effect brought on by its accumulation on ecology (Chang et al. 2006; Altas 2009). During recent times, heavy metals were focus of attention owing to their hazardous nature and subsequent toxicity studies. Various workers have assessed the combined toxicity of heavy metals ( $\mathrm{Su}$ et al. 2012; Qu et al. 2013; Mochida et al. 2006). It has been argued that the effects caused by combinations of various heavy metals may be more threatening and serious.

A characterization study of electroplating industry wastewater in Egypt concluded that $0.1 \mathrm{mg} / \mathrm{L} \mathrm{Pb}$ and $0.01 \mathrm{mg} / \mathrm{L} \mathrm{Cd}$ concentrations were dangerous for aquatic life (Wahaab et al. 2010). The concentrations of heavy metals beyond threshold values cause inhibition of the anaerobic process, the most suitable method to treat industrial wastewater (Wahaab et al. 2010). During anaerobic digestion processes of organic matter the biochemical reaction take place which are affected by the heavy metals presence (Mudhoo et al. 2012). The prime causes of such differences are the complication of the fermentation process leading to interactions like synergism, acclimation, antagonism and complex formation may seriously lead to inhibition. Inhibitory substances are often found to be the leading cause of anaerobic reactor upset and failure since they are present in substantial concentrations in wastewaters and sludge. A wide variety of substances have been reported to inhibit various stages of anaerobic treatment processes. Certain chemical is regarded as inhibitory if it poses serious alterations in the microbial population or may inhibit their growth (Chen 
et al. 2008). The heavy metals identified for causing serious harm include cobalt, iron, chromium, cadmium, zinc, nickel and copper (Gadd and White 1993). Heavy metals can be stimulatory, inhibitory, or even toxic for biochemical reactions, depending on their concentrations (Gikas and Romanos 2006). Generally waters receiving waste discharges are exposed to toxicant mixtures, rather than the single toxicant. So, there is a need to develop a quick method for assessing the individual and joint toxicity of the pollutants during the anaerobic treatment of industrial wastewater. During last year, risk of environmental pollutants was assessed by a variety of biological models, but the Microtox ${ }^{\circledR}$ test can easily detect the presence of toxicants (Fulladosa et al. 2005) by the light emitted by the $P$. phosphoreum in the standard laboratories. Different studies determined the toxicity of aromatic compounds, photolytic products and organic compounds (Parvez 2008; Jiao et al. 2008; Su et al. 2012). At the moment, the most suitable and delicate bioassay is the luminescent bacterium to assess the metal toxicities from industrial origin (Fulladosa et al. 2004, 2005; Li et al. 2001). The present study was conducted to assess the single metal toxicity and acute joint toxicity of $\mathrm{Cd}, \mathrm{Cu}$ and $\mathrm{Pb}$ by $P$. phosphoreum $\mathrm{T} 3$. Two different models were employed to assess the two combined and joint toxicity of the heavy metals in this study.

\section{Material and methods}

\section{Luminescent bacterium and chemicals}

The luminescent bacterium $P$. phosphoreum (T3 mutation) used in this study was bought form Institute of Soil Science, Chinese Academy of Sciences, Nanjing, China. The $P$. phosphoreum (T3 mutation) lyophilized concentrate was reenergized in $1 \mathrm{~mL} 2.5 \% \mathrm{NaCl}$ solution and kept in the ice water bath (Jiao et al. 2008). $\mathrm{CuCl}_{2} \cdot$ anhydrous, $\mathrm{CdCl}_{2}$ - $2 \mathrm{H}_{2} \mathrm{O}, \mathrm{PbCl}_{2}, \mathrm{NaOH}, \mathrm{NaCl}$ and $\mathrm{HCl}$ were bought from Sinopharm Chemical Reagent Co., Ltd., China (analytical reagent).

\section{Heavy metal samples preparation}

Three heavy metals $\mathrm{Cd}, \mathrm{Cu}$ and $\mathrm{Pb}$ were selected for this toxicity study. A standard procedure was adopted to prepare metal stock solutions $(1000,100,10$ and $1 \mathrm{mg} / \mathrm{L})$ by liquefying the equivalent salt in ultrapure water. The stock solutions were produced on the same day of experiment but sporadically stockpiled for a day at $4{ }^{\circ} \mathrm{C}$. Ten different concentrations of each single metal and eleven different concentrations of binary mixture and joint mixture of heavy metals were prepared.

\section{Toxicity assay}

Microtox Toxicity Analyzer (DXY-2, manufactured by the Nanjing Institute of Soil Science, The Chinese Academy of Science) was employed in conducting the toxicity tests (Ventura et al. 2012). A vessel holding $0.5 \mathrm{~g}$ of freeze-dried luminescent bacteria was broken very carefully and mixed with $0.8-1 \mathrm{~mL}$ cold $2.5 \% \mathrm{NaCl}$ solutions using $1 \mathrm{~mL}$ injector and then fully mixed. The mixture was transferred to a small vessel. Activated luminescent bacterial solution $(10 \mu \mathrm{L})$ was put into a test tube containing $2 \mathrm{ml}$ of $3 \%$ $\mathrm{NaCl}$ solution. The test bottle was fully mixed and put into the Microtox Toxicity Analyzer (DXY-2). The scale of initial luminosity should be in range of 600-1900 mV. If the initial luminosity does not reach the standard, newly freeze-dried powder of luminescent bacteria must be used.

\section{Individual acute toxicity of heavy metals}

The customary toxicity measurement procedure was engaged for the acute toxicity assay regarding various chemicals (International Standards Organization, 1994). Preliminary experiment was carried out to know the best metal concentration array for determining IC50 value of particular heavy metals $(\mathrm{Cd}, \mathrm{Cu}$ and $\mathrm{Pb})$ for this study. The heavy metals concentration range was between 0.01 and $20 \mathrm{mg} / \mathrm{L}$ to obtain the data on toxic effects of the individual metals. Ten concentration grades of individual chemicals were set from the stock solutions. The samples were diluted using $3 \% \mathrm{NaCl}$ solution at $20-25{ }^{\circ} \mathrm{C}$. The $\mathrm{pH}$ of test chemicals solutions was accustomed to $5.5-6$ by $0.1 \mathrm{M}$ $\mathrm{NaOH}$ or $\mathrm{HCl}$. The $\mathrm{pH}$ of the $2.5 \% \mathrm{NaCl}$ and $3 \% \mathrm{NaCl}$ diluent solution was also adjusted to $\mathrm{pH}$ 5.5-6 used in Microtox basic test protocol to guarantee the $\mathrm{pH}$ steadiness during the analyses (Fulladosa et al. 2004). Each sample concentration and a control was replicated three times. For the assay, the luminescent bacterium was kept in the ice water bath, $2 \mu \mathrm{L}$ of activated $P$. phosphoreum T3 were added into the tubes containing $2 \mathrm{~mL}$ of heavy metal solution and control ( $3 \% \mathrm{NaCl}$ solution). After an exposure of $15 \mathrm{~min}$ at $20-25^{\circ} \mathrm{C}$, Model Toxicity Analyzer measured the reduction in bioluminescence (indication of the toxicity). In China this method is a nationally standardized method. The bacteria are exposed to a range of concentrations of the material being tested. The reduction in intensity of light emitted from the bacterial culture was noted. The variation in light output and concentration of the toxicant produces a dose/response relationship. The results were normalized and the $15-\mathrm{min} \mathrm{IC}_{50}$ was compiled. Equation (1) helped to obtain the relative luminescence units (RLU), developed by the mean luminescence unit (LU) in the samples and the mean luminescence unit $\left(\mathrm{LU}_{0}\right)$ in the controls (without toxicant). 
$\mathrm{RLU}=\frac{\mathrm{LU}}{\mathrm{LU}_{0}} \%$

The concentration causing $50 \%$ relative luminescence unit was obtained by the regression equation and used as the 15 -min half inhibitory concentration $\left(15-\mathrm{min} \mathrm{IC}_{50}\right)$.

\section{Combined toxicity of three heavy metals}

According to the $15-\mathrm{min} \mathrm{IC}_{50}$ of single chemical, four groups of chemical mixture were prepared according to equitoxic ratio mixing method (De Laender et al. 2009; Tian et al. 2012). In this experiment, different concentrations were prepared for the two metals to get the $\mathrm{IC}_{50}$ close to the mid-point of each metal concentration range. The concentrations of two combined metals were between 0.01 and $10 \mathrm{mg} / \mathrm{L}$. In this study, according to equitoxic mixing ratio, i.e., toxicants were mixed according to $\mathrm{IC}_{50}$ of the single mixture for taking joint effects on diverse mixture, so it is:

$X_{a}=\frac{\mathrm{IC}_{50(a)}}{\mathrm{IC}_{50(a)}+\mathrm{IC}_{50(b)}+\cdots+\mathrm{IC}_{50(n)}}$

In this way, three binary mixtures $\mathrm{Cd}+\mathrm{Cu} ; \mathrm{Cd}+\mathrm{Pb}$; $\mathrm{Cu}+\mathrm{Pb}$ and one ternary mixture $\mathrm{Cd}+\mathrm{Cu}+\mathrm{Pb}$ were prepared. For each combination eleven different concentrations were prepared in triplicates. The tests for mixtures were conducted in a similar manner as that for the individual chemicals.

\section{Mathematical modeling for assessment of combined heavy metals toxicity}

According to Zheng and Feng (2006), the joint toxicities include four main types: independent effect (INE), additive effect (ADE), synergistic effect (SYE) and antagonistic effect (ANE). Different approaches used to assess the combined toxicities include toxic unit (TU) (Marking and Dawson 1975) and mixture toxic index (MTI) (Konemann 1981). In this study, the combined toxicities of multicomponent mixtures were assessed by TU and MTI approaches.

\section{Toxic unit $(T U)$}

In this approach, incipient LCs of the individual compounds are determined; so, Toxic Unit (TU) can be defined as the incipient $\mathrm{LC}_{50}$ for each compound. Toxic Unit (TU) is calculated by Eq. 3 .

$\mathrm{TU}_{i}=\frac{C_{i}}{\mathrm{IC}_{50, i}}$

where ci represents the concentration of $i$ when the mixture is at its $\mathrm{IC}_{50}, \mathrm{IC}_{50, i}$ is median inhibition concentration, TU $i$ is the toxic unit of $i$.
In Eq. $4, M$ is the sum of the toxic units.

$M=\sum_{i=1}^{\mathrm{n}} \mathrm{TU}_{\mathrm{i}}=\frac{C_{1}}{\mathrm{IC}_{50,1}}+\frac{C_{2}}{\mathrm{IC}_{50,2}}+\cdots+\frac{C_{n}}{\mathrm{IC}_{50, n}}$

In Eq. $5 \mathrm{M} 0$ is the ratio of $\mathrm{M}$ and (TUi) $\max$, where (TUi) $\max _{\max }$ is the maximum toxic unit of the mixture.

$M_{0}=\frac{M}{\left(\mathrm{TU}_{i}\right)_{\max }}$

Mixture toxic index (MTI)

The other approach used to assess the joint toxicity effect was Mixture Toxic Index (MTI), which can be calculated by the Eq. 5 (Konemann 1981).

MTI $=1-\frac{\log \mathrm{M}}{\log \mathrm{M}_{0}}$

In case of MTI indices values lower than 0 , the mixture potency was considered as antagonistic; if it equaled 0 , there was no addition; when it fell between 0 and 1 , the mixture potency was considered as partial additive; when it equaled 1, the mixture potency was said to be additive, and when it was greater than 1 , the mixture potency was defined as supra-additive.

The effect of joint toxicity can also be characterized by $M$ and $M_{0}$, the details of which can be seen as follows: if $M<1$, the joint toxicity is synergistic; if $M=1$, the joint toxicity is simply additive; if $M>M_{0}$, the joint toxicity is believed as antagonistic; if $M=M_{0}$, the joint toxicity is independent and if $M_{0}>\mathrm{M}>1$, the joint toxicity is partly additive. Besides, if the $95 \%$ confidence interval of $M$ includes 1 , the joint toxicity was additive in nature.

\section{Data analysis}

The $\mathrm{IC}_{50 \text { s }}$ were assessed as the concentrations equivalent to $50 \%$ decrease in light output. A dose-response relationship curve was constructed by plotting the percentages of reduction in bioluminescence correspondence to $Y$ values against metal concentrations. Digital data processing and the statistical data analysis of variance, linear fitting, correlation coefficient $(R)$ and confidence interval in the experiments were performed using Origin pro 8 software and SPSSTMv.18 statistical software.

\section{Results and discussion}

\section{Single metal toxicity analysis}

$\mathrm{IC}_{50}$ values for $P$. phosphoreum $\mathrm{T} 3$ during $15 \mathrm{~min}$ exposure to single metal solutions are presented in Table 1. The 
Table 1 Individual toxicities of four heavy metals at $\mathrm{pH} 5.5$ to 6

\begin{tabular}{llll}
\hline Pollutants & Linear regression equation & $\begin{array}{l}\text { Correlation } \\
\text { coefficient }\left(r^{2}\right)\end{array}$ & $\begin{array}{l}15-\mathrm{min} \mathrm{IC}_{50}^{\mathrm{a}} \\
(\mathrm{mg} / \mathrm{L})\end{array}$ \\
\hline $\mathrm{Cd}$ & $y=-68.136 x+86.622$ & 0.924 & 0.537 \\
$\mathrm{Cu}$ & $y=-19.507 x+87.157$ & 0.869 & 1.905 \\
$\mathrm{~Pb}$ & $y=-30.116 x+87.084$ & 0.923 & 1.231 \\
\hline
\end{tabular}

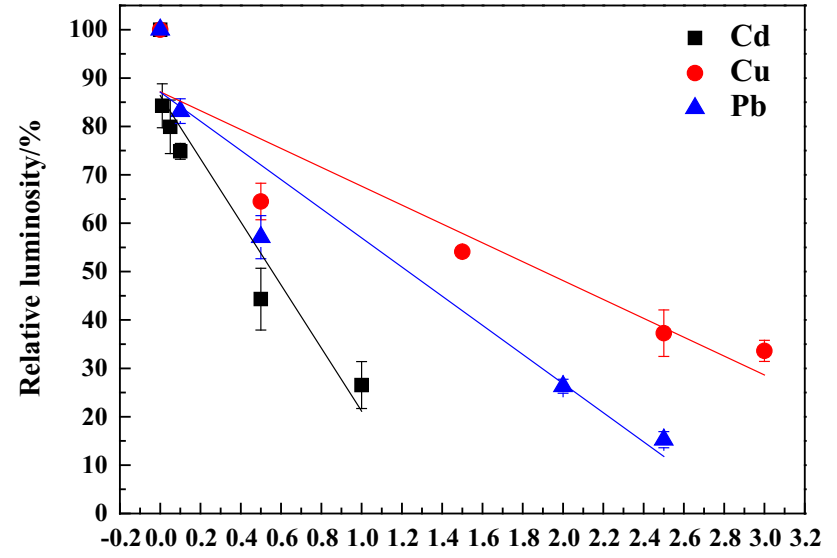

Fig. 1 Dose-response relationship of the $\mathrm{Cd}(\mathbf{a}), \mathrm{Cu}(\mathbf{b})$ and $\mathrm{Pb}$ (c) and comparison of the relative luminosity of the individual heavy metals (d)

15-min $\mathrm{IC}_{50}$ values of the single metal ranged from low to high: $\mathrm{Cd}$ (II) $<\mathrm{Pb}<\mathrm{Cu}$, i.e., $0.537,1.905$ and $1.231 \mathrm{mg} /$ $\mathrm{L}$, respectively. So it is clear from the single $15-\min \mathrm{IC}_{50}$ values shown that of three different heavy metals, $\mathrm{Cd}$ is found to be the most toxic heavy metal. The dose-response relationship of each heavy metal is shown in the Fig. 1. The linear regression equation $y=-68.136 x+86.62$ in dose-response relationship of $\mathrm{Cd}$ and $r^{2}=0.924$ depicted a very positive correlation. There was very slight difference in the $\mathrm{IC}_{50}$ values of the $\mathrm{Cd}$ and the $\mathrm{Pb}$ (Table 1) which had almost same $r^{2}$ values, i.e., 0.924 and 0.923 , respectively.

The toxicity of the single heavy metals in soil on $P$. phosphoreum was studied and the $\mathrm{EC}_{50}$ of values were $\mathrm{Cd} 26.12 \mathrm{mg} \cdot \mathrm{kg}^{-1}, \mathrm{Cu} 291.48 \mathrm{mg} \cdot \mathrm{kg}^{-1}$, and $\mathrm{Pb}$ $2174.93 \mathrm{mg} \cdot \mathrm{kg}^{-1}$, showing that $\mathrm{Cd}$ was the most toxic heavy metal among the three (Li et al. 2001).

Maintenance of $\mathrm{pH}$ has been observed as serious issue during toxicity assessment. The $\mathrm{pH}$ values of metal mixtures were maintained in the range of 5.5-6 in the present study. $\mathrm{Cd}$ precipitated at $1000 \mu \mathrm{mol} / \mathrm{L}(\mathrm{pH} 7)$ down to $50 \mu \mathrm{mol} / \mathrm{L}$ ( $\mathrm{pH} 8.5$ ). Possibly some $\mathrm{Cd}$ precipitation arose below these levels which seemed as prime reason of $100 \%$ inhibition in Cd experiments (Peterson et al. 1984). So we can say that the influence of the $\mathrm{pH}$ value upon heavy metal toxicity is supposed to rely on chemical species. It has been proved by different studies that in general, the toxicity of
$\mathrm{Cd}$ on $P$. phosphoreum was inversely related to $\mathrm{pH}$. It has been investigated that the effect of $\mathrm{pH}$ on metal toxicity is twofold: the hydrogen ion may exert its effect either directly by affecting metal uptake or indirectly by affecting the chemical speciation and bioavailability of the dissolved metal pool ( $\mathrm{Qu}$ et al. 2013). The 15-min $\mathrm{EC}_{50}$ value increased approximately to 13 -fold when the $\mathrm{pH}$ was decreased from 8.0 to 5.0 .

At high $\mathrm{pH}$ the $\mathrm{EC}_{50}$ decreased to a minimum value, and the cadmium species distribution was changed considerably. Interactions of the three major species, $\mathrm{Cd}\left(\mathrm{CO}_{3}\right)_{2}^{2-}$, $\mathrm{CdCl}^{+}$, and $\mathrm{CdCl}_{2}$, might be responsible for the high toxicity (Peterson et al. 1984; Pynnonen 1990; Villaescusa et al. 1996). It has been reported that the $\mathrm{IC}_{50}$ values, in toxicity tests where $\mathrm{pH}$ was changed, generally decreased as $\mathrm{pH}$ increased from 5.0 to 9.0. Clifford and McGeer (2010) found similar results that there was a general trend toward increased $\mathrm{IC}_{50}$ values of cadmium to Daphnia pulex when $\mathrm{pH}$ had decreased from 8.02 to 6.10 . However, Niyogi et al. (2008) did not observe any change in acute toxicity of $\mathrm{Cd}$ on rainbow trout across a $\mathrm{pH}$ range of 5.8-8.8.

The linear correlation between $\mathrm{Cd}^{2+}$ toxicity and $\mathrm{pH}$ clearly indicates that there is possible proton competition at the biotic ligand. A similar competitive interaction was also observed in Daniorerio (Komjarova and Blust 2009) and Pimephalespromelas (Playle 2004).The relationship between $\mathrm{pH}$ and $\mathrm{Cd}$ toxicity is very strong (Peterson et al. 1984). The competitive interactions between $\mathrm{H}^{+}$and $\mathrm{Cd}^{2+}$ may explain the toxicity mitigation caused by proton $(\mathrm{Qu}$ et al. 2013). So our results are similar to this study, that the correlation coefficients $(r)$ value for $\mathrm{Cd}$ and $\mathrm{Pb}$ was 0.924 and 0.923 , respectively, at $\mathrm{pH} 5.5-6$. The present results showed $\mathrm{Cd}^{+2}$ as the most toxic heavy metal than $\mathrm{Cu}$ and $\mathrm{Pb}$ to $P$. phosphoreum. Anaerobic metabolism has shown to be strongly affected by the presence of metals (Mrafkova et al. 2003; van Hullebusch et al. 2004). Unlike many other toxic substances, heavy metals are not biodegradable and can accumulate to potentially toxic concentrations (Sterritt and Lester 1980).The toxic effect of heavy metals is attributed to disruption of enzyme function and structure by binding of the metals with thiol and other groups on protein molecules or by replacing naturally occurring metals in enzyme prosthetic groups (Sterritt and Lester 1980). Heavy 
metal concentrations that caused $50 \%$ inhibition of methanogenesis during whey methanation indicated that toxicity decreased in the order of $\mathrm{Cu}>\mathrm{Zn}>\mathrm{Ni}$. Similar results were obtained by Lin (1992, 1993), Nies (1999) and Lin and Chen (1999). The relative sensitivity of anaerobic process to heavy metals was $\mathrm{Cd}>\mathrm{Cu}>\mathrm{Cr}>\mathrm{Zn}>$ $\mathrm{Pb}>\mathrm{Ni}$, respectively (Lin 1992, 1993).

\section{Combined heavy metals toxicity analysis}

Equitoxic metal binary and three combined mixtures were prepared on the basis of concentrations of each heavy metal, a similar toxic effect produced when being alone. Both experimental and theoretical 15-min $\mathrm{IC}_{50}$ values of the different binary metal mixtures and three combined metal mixtures are presented in Table 2.

Statistical parameters like linear regression equation and $R^{2}$ values are also given in Table 2 . The two combined and joint mixture $R^{2}$ values were $0.969,0.9036,0.9266$ and 0.9548, respectively, which showed a linear relationship between the relative luminosity $\%$ and heavy metals concentration in a mixture, which is clearly depicted in the Fig. 2. The theoretical $15-\mathrm{min} \mathrm{IC}_{50}$ values for $\mathrm{Cd}+\mathrm{Cu}$, $\mathrm{Cd}+\mathrm{Pb}, \mathrm{Cu}+\mathrm{Pb}$ and $\mathrm{Cd}+\mathrm{Cu}+\mathrm{Pb}$ were 1.22, 0.88, 1.57 and $1.84 \mathrm{mg} / \mathrm{L}$, respectively.

Two mathematical models were applied to calculate the interaction effects between two and three metals. According to toxic unit (TU) approach toxic units of single heavy metals and sum of the toxic units in a mixture were calculated according to the Eqs. (3) and (4), respectively; results are shown in Table 3.

The results of two mathematical approaches are compared in the Table 3 and similar interaction was anticipated by the two statistical approaches. Both approaches indicate that two over three of the studied binary mixtures presented as antagonistic and one binary mixture showed partly additive effect. It can be discussed that the $\mathrm{Cd}, \mathrm{Cu}$ and $\mathrm{Cd}, \mathrm{Pb}$ effect was considered as antagonistic when the statistical confidence level was $95 \%$. The dose-response relationship or the relative luminosity of the two combined heavy metals mixture is shown in the Fig. 2a.
The results suggested that $\mathrm{Cd}+\mathrm{Cu}$ and $\mathrm{Cd}+\mathrm{Pb}$ effects were antagonistic, as $\mathrm{IC}_{50}$ values are higher than the TU values (Table 2). An antagonism between two metals suggests that they act on two different steps of the same energy-producing pathway. Same antagonistic result was oriented by the application of the TU and MTI approach while calculating the combined effects of the $\mathrm{Cd}, \mathrm{Cu}$ and $\mathrm{Cd}, \mathrm{Pb}$.

Two combined heavy metals $\mathrm{Cu}$ and $\mathrm{Pb}$ showed the partly additive effect. According to MTI approach, if MTI $>0$ but $<1$ the effect is partly additive, this can clearly be depicted as $0.81>0$ but $0.81<1$ from Table 4 . According to TU approach when $\mathrm{M}_{0}>\mathrm{M}>1$, the effect would be partly additive, so the combined effect of $\mathrm{Cu}$ and $\mathrm{Pb}$ was found partly additive. So, by comparing the results of the two mathematical approaches/models in the Table 3, it was observed that the results calculated from the two different methods were same for the two different combinations of the heavy metals. It is concluded that these two approaches are effective in the determination of the combined effect of the toxicants on $P$. phosphoreum T3.

Similarly for three combined heavy metals $(\mathrm{Cd}, \mathrm{Cu}$ and $\mathrm{Pb})$, the partly additive effect was observed by the TU and

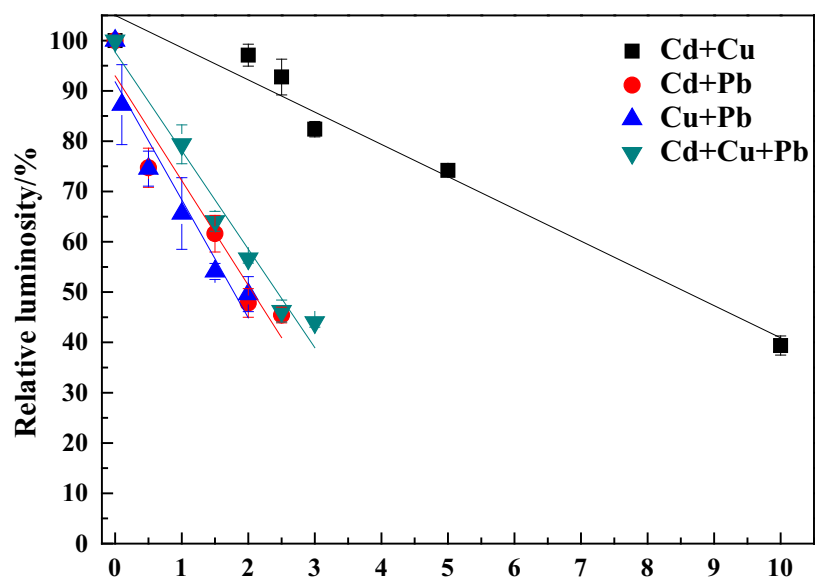

Fig. 2 a Dose-response relationship of two combined heavy metals. b Dose-response relationship of joint heavy metals. c Relative luminosity percentage of the two combined and joint heavy metals

Table 2 Experimental versus expected 15 -min $\mathrm{IC}_{50}$ values of two combined and joint metals inducing a $50 \%$ by Photobacterium phosphoreum after 15 min exposure, according to the Microtox protocol

\begin{tabular}{lllll}
\hline Mixtures & Linear regression equation & $r^{2}$ & Experimental & Theoretical 15-min \\
& & & 15-min $\mathrm{IC}_{50}(\mathrm{mg} / \mathrm{L})$ & $\begin{array}{l}\mathrm{IC}_{50}(\mathrm{mg} / \mathrm{L}) \\
\mathrm{Cd}+\mathrm{Cu}\end{array}$ \\
$\mathrm{Cd}+\mathrm{Pb}$ & $y=-6.148 x+105.01$ & 0.969 & 8.947 & 1.22 \\
$\mathrm{Cu}+\mathrm{Pb}$ & $y=-20.521 x+92.6$ & 0.9036 & 2.11 & 0.88 \\
$\mathrm{Cd}+\mathrm{Cu}+\mathrm{Pb}$ & $y=-19.384 x+97.365$ & 0.9266 & 1.781 & 1.57 \\
\end{tabular}


Table 3 Toxic Unit (TU) of single heavy metals and sum of the toxic units in two combined and joint mixtures of heavy metals

\begin{tabular}{|c|c|c|c|c|c|}
\hline \multirow[t]{2}{*}{ Mixtures } & \multirow{2}{*}{$\begin{array}{l}\text { Experimental } \\
15 \text {-min } \mathrm{IC}_{50}(\mathrm{mg} / \mathrm{L})\end{array}$} & \multicolumn{3}{|c|}{ Toxic Unit of Individual Heavy metals } & \multirow{2}{*}{$\begin{array}{l}\text { Sum of Toxic Units } \\
\text { in a mixture }(\mathrm{M})\end{array}$} \\
\hline & & $\mathrm{TU}_{C d}$ & $\mathrm{TU}_{C u}$ & $\mathrm{TU}_{P b}$ & \\
\hline $\mathrm{Cd}+\mathrm{Cu}$ & 8.581 & 3.665 & 3.665 & - & 7.330 \\
\hline $\mathrm{Cd}+\mathrm{Pb}$ & 2.076 & 1.193 & - & 1.193 & 2.386 \\
\hline $\mathrm{Cu}+\mathrm{Pb}$ & 1.781 & - & 0.567 & 0.567 & 1.135 \\
\hline $\mathrm{Cd}+\mathrm{Cu}+\mathrm{Pb}$ & 2.443 & 0.664 & 0.664 & 0.664 & 1.992 \\
\hline
\end{tabular}

Table 4 Comparison results of two and three combined heavy metal effects calculated by the TU and MTI approach

\begin{tabular}{lllllll}
\hline Mixtures & $\left(r^{2}\right)$ & $15-\operatorname{min~IC}_{50}^{\mathrm{a}}(\mathrm{mg} / \mathrm{L})$ & $M$ & Interact effect & MTI & Interact effect \\
\hline $\mathrm{Cd}+\mathrm{Cu}$ & 0.969 & 8.581 & 7.733 & ANT & -1.87 & ANT \\
$\mathrm{Cd}+\mathrm{Pb}$ & 0.9036 & 2.076 & 2.38 & ANT & -0.255 & ANT \\
$\mathrm{Cu}+\mathrm{Pb}$ & 0.9266 & 1.781 & 1.13 & partly ADE & 0.81 & partly ADE \\
$\mathrm{Cd}+\mathrm{Cu}+\mathrm{Pb}$ & 0.9548 & 2.443 & 1.99 & partly ADE & 0.37 & partly ADE \\
\hline
\end{tabular}

$A N T$ antagonistic effect, $A D E$ additive effect $C I$ confidence interval, $M$ sum of the toxic units in a mixture, $M T I$ mixture toxicity index

MTI approaches in this study. The additive effect of the two combined and three combined heavy metals was due to the kindred structure and the same action mechanism.

The statistical approaches to evaluate the combined heavy metals toxicity at different concentration gradient may not be similar in various studies. Fulladosa et al. (2005) reported the additive, antagonistic and antagonistic effect of $\mathrm{Cd}+\mathrm{Cu}, \mathrm{Cd}+\mathrm{Pb}$ and $\mathrm{Cu}+\mathrm{Pb}$, respectively. This present study's heavy metals combination result suggested that cadmium may lower or even overwhelm the lead toxic effect. An additive effect was also reported by Mowat and Bundy (2002) of lead and cadmium in equal concentration but as antagonistic when the lead concentration was of 25 and $55 \%$ in the combined mixture of lead and cadmium. An antagonistic effect was investigated when $\mathrm{Cd}+\mathrm{Pb}$ mixtures were analyzed to know the toxicity on Vibrio fischeri. So, there is need to explore the $\mathrm{Cd}+\mathrm{Cu}$ antagonistic effect on $P$. phosphoreum in detail (Qureshi et al. 1982).

The differential responses of test organisms to mixtures of metals might be ascribed to modifications in the molecular interactions between the element and key cellular events. It may be related to: (1) the mechanisms responsible for the absorption by the bacterial cells, i.e., diffusion across membrane, transport process and composition of the cell wall, (2) interactions of the toxic elements with enzymes or allosteric effectors (3) interactions with the luciferase complex which is responsible for the luminescence. Very specifically, in the case of the Microtox ${ }^{\circledR-}$ test, the sensitivity of the luciferase complex to toxic elements must be considered as a near indicator of a noxious effect. Effect on other parameters such as bacterial growth rate or mortality would be delayed (Gellert, 2000; Fulladosa et al. 2005).

\section{Conclusions}

So it is concluded on the basis of results that the toxicity of the $\mathrm{Cd}$ was found to be higher when compared to $\mathrm{Cu}$ and $\mathrm{Pb}$. The two over three groups of two combined metals showed antagonistic effects, while one was partly additive. The joint metals effect was found to be partly additive. The application of two different mathematical models showed the similar effects for all combination of heavy metals.

Keeping in view the environmental safeguard, antagonistic effect cannot be taken into account in designing the discharge limits; the reason is that such effect cannot be anticipated for all possible combinations of the toxicants in an industrial effluent. We cannot ignore such pollutants when we are optimizing a biological treatment plant for industrial wastewater treatment. So, it is significant that the concentration of each metal remains within the established limit; the total concentration of the constituent must be below the threshold value. It is very important that all synergistic effects must be reported very carefully.

As the Microtox ${ }^{\circledR}$ bioluminescent test is the most robust and reliable for assessing the heavy metal toxicity in industrial wastewater treatment through anaerobic digestion. The toxicity results of Photobacterium phosphoreum would be helpful in the optimization and stable performance of the bioreactors, and information about the heavy metals toxicity at different concentration gradients would 
also be very useful to environmental engineers for the timely corrective measures.

Open Access This article is distributed under the terms of the Creative Commons Attribution 4.0 International License (http:// creativecommons.org/licenses/by/4.0/), which permits unrestricted use, distribution, and reproduction in any medium, provided you give appropriate credit to the original author(s) and the source, provide a link to the Creative Commons license, and indicate if changes were made.

\section{References}

Altas L (2009) Inhibitory effect of heavy metals on methaneproducing anaerobic granular sludge. J Hazard Mater 162:1551-1556

Chang WC, Hsu GS, Chiang SM, Su MC (2006) Heavy metal removal from aqueous solution by wasted biomass from a combined AS-biofilm process. Bioresour Technol 97:1503-1508

Chen Y, Cheng J, Creamer SK (2008) Inhibition of anaerobic digestion process: a review. Bioresour Technol 99:4044-4064

Clifford M, McGeer JC (2010) Development of a biotic ligand model to predict the acute toxicity of cadmium to Daphnia pulex. Aquat Toxicol 98:1-7

De Laender F, Janssen CR, De Schamphelaere KAC (2009) Nonsimultaneous ecotoxicity testing of single chemicals and their mixture results in erroneous conclusions about the joint action of the mixture. Chem 76:428-432

Fulladosa E, Murat JC, Martinez M, Villaescusa I (2004) Effect of pH on arsenate and arsenite toxicity to luminescent bacteria (Vibrio fischeri). Arch Environ Contam Toxicol 46:176-183

Fulladosa E, Murat JC, Martınez M, Villaescusa I (2005)Patterns of metals and arsenic poisoning in Vibrio fischeribacteria.Chem 60 , 43-48

Gadd GM, White C (1993) Microbial treatment of metal pollution-a working biotechnology. Trends Biotechnol 11:353-359

Gellert G (2000) Sensitivity and significance of luminescent bacteria in chronic toxicity testing based on growth and bioluminescence. Ecotoxicol Environ Safe 45:87-91

Gikas P, Romanos P (2006) Effects of tri-valent (Cr(III)) and hexavalent $(\mathrm{Cr}(\mathrm{VI}))$ chromium on the growth of activated sludge. J Hazard Mater 133:212-217

International Standards Organization, Water quality determination of the inhibitory effect of water samples on the light emission of Vibrio fischeri (luminescent bacteria test), 1994, ISO11348-2, Geneva, Switzerland

Jiao S, Zheng S, Yin D, Wang L, Chen L (2008) Aqueous photolysis of tetracycline and toxicity of photolytic products to luminescent bacteria. Chem 73:377-382

Komjarova I, Blust R (2009) Effects of $\mathrm{Na}, \mathrm{Ca}$, and $\mathrm{pH}$ on the Simultaneous Uptake of $\mathrm{Cd}, \mathrm{Cu}, \mathrm{Ni}, \mathrm{Pb}$, and $\mathrm{Zn}$ in the Zebrafish Daniorerio: a Stable isotope experiment. Environ Sci Technol 43:7958-7963

Konemann H (1981) Fish toxicity tests with mixtures of more than 2 chemicals - a proposal for a quantitative approach and experimental results. Toxicol 19:229-238

Li B, Li P, Wang J, Yang G, Zhang H (2001) Photobacterium phosphoreum assay on the toxicity of soil contaminated by heavy metals. J Appl Ecol 12:443-446 (Chinese)

Lin CY (1992) Effect of heavy metals on volatile fatty acid degradation in anaerobic digestion. Water Res 26:177-183

Lin CY (1993) Effect of heavy metals on acidogenesis in anaerobic digestion. Water Res 27:147-152
Lin CY, Chen CC (1999) Effect of heavy metals on the methanogenic UASB granule. Water Res 33:409-416

Marking L, Dawson VK (1975) Method of assessment of toxicity or efficacy of mixture of chemical. Invest Fish Control USFWS $67: 1-8$

Mochida K, Ito K, Harino H, Kakuno A, Fujii K (2006) Acute toxicity of pyrithione anti fouling biocides and joint toxicity with copper to red sea bream (Pagrus major) and toy shrimp (Heptacarpusfutilirostris). Environ Toxicol Chem 25:3058-3064

Mowat FS, Bundy KJ (2002) Experimental and mathematical/computational assessment of the acute toxicity of chemical mixtures from the Microtox ${ }^{\circledR}$ assay. Advanc Environ Res 6:547-558

Mrafkova L, Goi D, Gallo V, Colussi I (2003) Preliminary evaluation of inhibitory effects of some substances on aerobic and anaerobic treatment plant biomasses. Chem Biochem Eng Quart 17:243-247

Mudhoo A, Pravish RM, Romeela M (2012) Effects of microwave heating on biogas production, chemical oxygen demand and volatile solids solubilization of food residues, World Academy of Science. Engine Technol 69:805-810

Nies DH (1999) Microbial heavy-metal resistance. Appl Microbiol Biotechnol 51:730-750

Niyogi S, Kent R, Wood CM (2008) Effects of water chemistry variables on gill binding and acute toxicity of cadmium in rainbow trout (Oncorhynchusmykiss): a biotic ligand model (BLM) approach. Comp Biochem Physiol 148C:305-314

Parvez S,Bioluminescence Inhibition Based Toxicity Assessment of Hydrophobic Organic Compounds: Component Contribution to Mixture Toxicity, Ph.D thesis., IIT Bombay. Mumbai., 2008, pp 34-65

Peterson HG, Healey FP, Wagemann R (1984) Metal toxicity to algae: a highly pH dependant phenomenon. Can J Fish Aquat Sci 41:974-979

Playle RC (2004) Using multiple metal-gill binding models and the toxic unit concept to help reconcile multiple-metal toxicity results. Aquat Toxicol 67:359-370

Pynnonen K (1990) Effect of acidic conditions on cadmium kinetics and electrolyte balance in the fresh water clam Uniopictorum. Ann Zoolog Fennici 27:351-360

Qu R, Wang X, Liu Z, Yan Z, Wang Z (2013) Development of a model to predict the effect of complexing agents on the acute toxicity of cadmium to Photobacterium phosphoreum. J Hazard Mater 262:288-296

Qureshi AA, Flood KW, Thompson SR, Janhurst SM, Inniss CS, Rokosh DA (1982) Comparison of luminescent bacterial test with other bioassays for determining toxicity of pure compounds and complex effluents. In: Foster JG, RB, Bishop WE (Eds) Aquatic Toxicology and Hazard Assessment: Fifth Conference, ASTM STP 766, Pearson, Am Soc Test Mater, pp 179-195

Sterritt RM, Lester JN (1980) Interaction of heavy metals with bacteria. Sci Total Environ 14:5-17

Su L, Zhang X, Yuan X, Zhao Y, Zhang D, Qin W (2012) Evaluation of joint toxicity of nitro aromatic compounds and copper to Photobacterium phosphoreum and QSAR analysis. J Hazard Mater 241:450-455

Tian DY, Lin ZF, Yu JQ, Yin DQ (2012) Influence factors of multi component mixtures containing reactive chemicals and their joint effects. Chem 88:994-1000

van Hullebusch ED, Zandvoort MH, Lens PNL (2004) Nickel and cobalt sorption on anaerobic granular sludges: kinetic and equilibrium studies. J Chem Technol Biotechnol 79:1219-1227

Ventura SPM, Marques CS, Rosatella AA, Afonso CAM, Goncalves F, Coutinho JAP (2012) Toxicity assessment of various ionic liquid families towards Vibrio fischeri marine bacteria. Ecotoxicol Environ Saf 76:162-168 
Villaescusa I, Martinez M, Murat JC, Costa C (1996) Cadmium species toxicity on luminescent bacteria, Fresen. J Anal Chem 354:566-570

Wahaab RA, Moawad AK, Taleb EA, Ibrahim HS, El-Nazer HAH (2010) Combined photocatalytic oxidation and chemical coagulation for cyanide and heavy metals removal from electroplating wastewater. World Appl Sci J 8:462-469

Zheng P, Feng XS (eds) (2006) Biotechnology for waste treatment, Higher Education Press, Beijing 